\title{
Labor Market Rigidities and EMU
}

\author{
Carsten Hefeker* \\ University of Basel
}

\begin{abstract}
This paper explores the interaction between labor market deregulation, monetary union and unemployment. Monetary policy autonomy and monetary union are compared in their influence on the optimal level of labor market deregulation consented to and wages demanded by labor unions. EMU leads to higher real wages and higher unemployment when unions set their policies independently, but labor market regulation is unaffected. This is in constrast to results derived earlier in the literature. The paper also asks whether union cooperation improves on the non-cooperative results. That is not necessarily the case.
\end{abstract}

- JEL Classifications: E24, F02, F33

- Key Words: Monetary Union, Unemployment, Labor Unions

\section{Introduction}

It is frequently stated that rigidities in European labor markets are the main cause for the much higher unemployment in Europe than in the US. Not only are wages inflexible, but in addition working time regulation, hiring and firing costs, generous holiday allowments, and other social benefits make labor too expensive and thus increase unemployment. Therefore, economists and international organization demand a deregulation of labor markets to lower unemployment in Europe (see e.g. OECD, 1994; Siebert, 1997).

The connection between unemployment and the movement towards a monetary

\footnotetext{
*Corresponding Address: Petersgraben 51, 4003 Basel, Switzerland Tel: +41-61-267.3362, Fax: +41-61267.3340, Email: Carsten.Hefeker@ unibas.ch

(C)2001-Center for International Economics, Sejong Institution, All Rights Reserved.
} 
union for Europe has, however, mainly be drawn for the level of wages alone. It is often argued that a common money might trigger an equalization of nominal wage demands within the union, without taking account of different productivity levels (Jackman, 1997). More optimistic observers expect that wage demands are disciplined when labor realizes that the adjustment instrument exchange rate is lost (Horn and Persson, 1988). Other voices, such as union leaders, in turn have requested that nonwage labor costs and social protection be equalized across member countries to protect workers against a "race to the bottom" (see Hefeker, 1999).

Despite these union demands, relatively little has been said so far by economists about the incentives to deregulate labor markets beyond the nominal wage rigidity in a monetary union. First steps to derive how wage demand and demand for social regulation interact, and how this interaction is affected by the movement to a common currency, have been taken by Calmfors (2000) and Sibert and Sutherland (2000) who analyze how the incentives of governments to tackle labor markets rigidities are affected by monetary union (see also Belke and Kamp, 1999). If deregulation serves as an alternative to monetary expansion to lower unemployment, governments have an incentive to use labor market deregulation instead of monetary policy to counter unemployment. By moving to EMU, however, the time-consistency problem is automatically reduced because the common central bank, the European Central Bank (ECB), cares relatively little for any single country. Governments therefore have less incentives to use labor market deregulation to lower the monetary time-consistency problem.

Although providing an important impression on the relation between EMU and labor market regulation, these papers disregard one important aspect. Is not clear that governments alone can directly control and change the degree of labor markets rigidities. While this might adequately describe the working of labor markets in Anglo-Saxon countries, it is probably less appropriate for continental European countries. There attempts at deregulation very often meet with fierce protests from labor organizations (see, e.g., Saint-Paul, 1996). The extension of the workweek to weekends, the prolongation of shop opening hours, the reduction of hiring and firing costs, and the reduction of unemployment benefits are all measures that governments cannot autonomously change. Consent by labor unions is required to implement those policy reforms.

For this reason, it is important to complement the analysis of governments' incentives by asking in how far labor organizations are willing to agree to deregulation of labor markets. In reality, the amount of labor market regulation is 
likely to be a compromise between what labor unions want and what governments want. To see how far the results focusing on governments alone are robust, I concentrate on the opposite polar case and consider the degree of deregulation that labor unions accept and how this would change in a monetary union (Sections 2 and 3). ${ }^{1}$ A game-theoretic model is developed that first analyses the interaction between a national central bank and a (single) national labor union and then turns to the interaction between a common central bank with several national labor unions. The result is that the optimal amount of deregulation is, in contrast to what the literature so far has derived, not affected by EMU. However, the introduction of a common central bank will lead at least some unions to set higher real wages and thus to increase unemployment. In Section 4, I discuss whether the outcome under EMU can be improved if unions coordinate wage setting and deregulation. It can improve on the non-cooperative outcome but still implies more unemployment for certain countries. It is even possible that coordination will create more unemployment than non-coordinated behavior. Section 5 concludes.

\section{Labor Unions, Central Banks, and Regulation in One Country}

To focus on the influence of monetary union on the incentives of unions to deregulate labor markets, I assume that product markets are competitive and perfectly integrated. ${ }^{2}$ In addition, it is assumed that purchasing power parity holds so that countries have no incentive to use monetary policy to achieve a real devaluation vis-à-vis other EU countries ${ }^{3}$.

The following time structure for the interaction between central banks, firms and unions is considered: (i) labor sets wages and agrees to a certain level of labor market deregulation, (ii) the central bank sets its monetary policy in reaction to this, (iii) firms observe the real wage and the level of regulation and hire labor

\footnotetext{
${ }^{1}$ Clearly, the reality might be somewhere in the middle, depending form country to country on the relative power of governments and labor unions. Note however that the approach chosen is at least compatible with models of monopoly labor unions which determine wages themselves (see Oswald 1985). It is only a shortcut for more sophisticated models of wage bargaining among labor and capital. In the context of monetary union such models have been used by Cukierman and Lippi (2000) or Grüner and Hefeker (1999).

${ }^{2}$ It has been shown that, if product markets are imperfectly competitive, labor unions have an incentive to set higher wages to increase their international purchasing power, trading it off against employment (Rama, 1994). I abstract from these effects.

${ }^{3}$ Thus, I do not consider the second effect mentioned by Sibert and Sutherland (2000) why EMU reduces to deregulate. Since beggar-thy-neighbor monetary policy disappears with monetary union, the inflation bias is additionally reduced which reduces incentives to deregulate the labor market.
} 
according to equation (1), thereby (iv) determining the rate of unemployment in the economy. The solution concept is subgame perfect Nash equilibrium.

Following Calmfors (2000), unemployment is determined as

$$
u_{i}=a\left(w_{i}-\pi_{i}-\delta_{i} s_{i}\right)
$$

where all variables express natural logarithms. For simplicity, the "equilibrium rate" of unemployment without labor market deregulation is normalized to one, so that its $\log$ is zero. Unemployment is increasing above this level as a function of the real wage $\omega_{i}-\pi_{i}$, and falling in the degree of labor market deregulation s. $\pi_{i}$ is the log of the price level; normalizing the price level in period $p_{t-1}=0$ it is the rate of inflation. The impact of labor market deregulation is expressed as $\delta_{i}$, which might differ from country to country. In this model labor market deregulation and lower real wages are hence both ways for increasing employment. Like Calmfors (2000), I summarize labor market deregulation in one variable so that s denotes an overall employment increasing program of abolishing labor market rigidities. ${ }^{4}$

Labor is organized in national unions who express the preferences of their members. Since identical firms are assumed to produce a homogenous good, it makes sense to represent union members by a single union that covers the whole country and maximizes the objectives of its members. The utility of the labor union in country $i$ is

$$
U_{i}=w_{i}-\pi_{i}\left(1-c_{i}\right)-\frac{\gamma_{i}}{2} s^{2}-\frac{\alpha}{2} u_{i}^{2}
$$

Union utility is increasing in real wages $w-\pi$ and decreasing in unemployment u (see e.g. Oswald, 1985). Following recent papers (see e.g. Cukierman and Lippi, 1999; Lawler, 2000; Cubitt, 1992), I include a term that measures the aversion of unions against inflation $c$, so that unions are concerned with inflation in two ways: it reduces real wages and affects utility directly. ${ }^{5}$ First, it affects the real wage and is thus included in $w-\pi$. However, this term implies that unions do not

\footnotetext{
${ }^{4}$ While this is a strong simplification, it can be justified by the fact that important complementarities between different regulations exist. As Coe and Snower (1997) show, only an overall fundamental labor market reform is likely to have beneficial effects on employment. In addition, it is not clear on which particular features of labor market regulation one should focus when discussing their interaction with a monetary union.

${ }^{5}$ Notice that the main results concerning the amount of deregulation derived below do not depend on the specific form of the utility function. It can be shown that the same result obtains with a utility function where inflation aversion is quadratic (available from the author upon request). The linear specifiction is chosen for simplicity only.
} 
care about inflation, they just care for the difference between nominal wages and inflation. Hence a given real wage is compatible with any level of inflation. But union members, like anybody else in society, are affected by the costs of inflation. If savings accounts, pensions claims, or government bonds that are held by members are not indexed, union members directly suffer from inflation be-cause it lowers their real wealth.

In addition, I have amended this model by the assumption that unions oppose labor market deregulation (cf. Calmfors, 2000). Thus, in contrast to equation (1) where low real wages and labor market deregulation can alternatively be used for increasing employment, they enter utility separately. ${ }^{6}$ This reflects the aforementioned fact that labor unions have target levels of labor market regulation and labor standards. Labor union utility is concave in wages and employment increasing labor market deregulation.

Finally, I allow for differences in the relative weights unions in different countries attach to inflation and labor market regulation. Some countries such as the UK are characterized by relatively flexible labor markets, whereas in countries such as Germany or France unions take to the streets if deregulation is proposed by the government, thus the r's differ across countries. On the other hand, societies such as Germany or Austria have a high concern for monetary stability, in this case the c's should be higher than in less inflation averse countries.

The second player in the pre- monetary union game in each country is the central bank. I assume that the labor union is aware of the reaction function of the central bank and thus acts as the Stackelberg leader because central banks follow a predictable policy course. Unions anticipate monetary policy and take this into account when formulating their wage demands.

For the preferences of the central bank, I assume a standard utility function

$$
V_{i}=-\frac{1}{2}\left(\pi_{i}^{2}+b_{i} u_{i}^{2}\right)
$$

so that the central bank aims to avoid deviations of unemployment from the natural rate and inflation. The strength of its aversion against unemployment is $b_{i}$.

The reaction of the central bank follows from the maximization of (3) with respect to inflation and yields

\footnotetext{
${ }^{6}$ Of course, one might debate whether wages and regulation enter unions' preferences additively. But evidence from countries such as Germany or France suggests this to be the case. Unions often declare target values for wage increases and e.g. working hours reduction separately.
} 


$$
\pi_{i}=\frac{a^{2} b_{i}}{1+a^{2} b_{i}}\left(w_{i}-\delta_{i} s_{i}\right) \equiv \Psi_{i}\left(w_{i}-\delta_{i} s_{i}\right)
$$

with reaction parameter $\Psi_{i}<1$. The central bank will not fully accommodate nominal wage demands and labor market rigidities. Monetary expansion is however increasing in the central bank's concern for employment and the marginal effect of monetary policy on employment.

The labor union sets $w$ and agrees to a certain amount of deregulation $s$. The nominal wage demand of the labor union and the amount of labor market deregulation it accepts follow from the maximization of (2) subject to (1) and (4). This yields

$$
w_{i}=\frac{1-\Psi_{i}\left(1+c_{i}\right)}{\alpha a^{2}\left(1-\Psi_{i}\right)^{2}}+\delta_{i} s_{i}
$$

and

$$
s_{i}=\frac{\delta_{i}}{\gamma_{i}}
$$

Not surprisingly, the nominal wage demand is increasing in labor market deregulation $s$. The lower the level of regulation, the higher is the level of employment. This induces labor to demand higher wages. It is also intuitive that the optimal labor market deregulation is increasing in $\gamma$ and decreasing in $\delta$. Because the union is inflation averse, it reduces its nominal wage demands when the central bank's reaction to these is strong. Therefore wage demands are reduced by $\Psi_{i}\left(1+c_{i}\right)$. An employment concerned central banker will hence induce discipline on unions' wage setting.

The real wage (denoted as $\ddot{w}$ ) follows from (4), (5) and (6) as

$$
\hat{w}_{i}=\frac{1-\Psi_{i}\left(1+c_{i}\right)}{\alpha a^{2}\left(1-\Psi_{i}\right)^{2}}+\frac{\delta_{1}^{2}}{\gamma_{i}}
$$

According to (1) this determines unemployment in country $i$ before monetary union as

$$
u_{i}=a \cdot \frac{1-\Psi_{i}\left(1+c_{i}\right)}{\alpha a^{2}\left(1-\Psi_{i}\right)} .
$$




\section{Labor Unions and Rigidities in EMU}

Let the European central bank follow the same objectives as the national central banks did before EMU, such that

$$
V_{E C B}=\frac{1}{N} \sum_{i}^{N} V_{i}
$$

The ECB's preferences are a weighted average of the national central banks' preferences, where all $\mathrm{N}$ members have the same weight. This is the most simple assumption one can make about the decision making in the European Central Bank (ECB). ${ }^{7}$ Moreover, since I do not wish to concentrate on changes that are exclusively due to the creation of the common central bank, I assume that the ECB has the same preferences as all central banks had before EMU and set $b_{i}=b$.

The rate of inflation in the monetary union then becomes

$$
\pi=\frac{1}{N} \sum_{i}^{N} \frac{a^{2} b}{\left(1+a^{2} b\right)}\left(w_{i}-\delta_{i} s_{i}\right) \equiv \theta \sum_{i}^{N}\left(w_{i}-\delta_{i} s_{i}\right)
$$

Notice that $\theta$ is a decreasing function of the number of countries that are member in the monetary union. This implies that the more countries are member of the union, the less the central bank cares for any single country. To simplify the algebra, I will subsequently assume that only two countries form the monetary union $(N=2$ or $\theta=\psi / 2)$.

In every single member country, the labor unions are now confronted with a different reaction function of the central bank than before. In addition, an interaction is created between the labor unions via the central bank. This is obvious from deriving the first order conditions of (2) now with respect to (10) to get the nominal wage demand under EMU

$$
w_{i}=\frac{(1-\theta)-\theta\left((1-\theta) c_{i}+\theta c_{j}\right)}{\alpha a^{2}(1-\theta)(1-2 \theta)}+\delta_{i} s_{i} .
$$

The nominal wage demands in country $i$ are now also affected by the inflation aversion of union $j$. The more inflation averse is union $j$, the lower the wage

\footnotetext{
${ }^{7}$ An obvious alternative would be that the median voter among the national representatives determines the common monetary policy (see Grüner, 1999). For the results derived it suffices that the common central bank cares less for developments in any country than the national bank. This is likely to result from most aggregation assumption about the ECB's preferences.
} 
demands from union $i$ will be. However, it also follows that the degree of labor market deregulation consented to by national labor unions is unchanged at

$$
s_{i}=\frac{\delta_{i}}{\gamma_{i}}
$$

Using (12) in (11) and subtracting (10), the real wage under EMU is

$$
\hat{w}_{i}=\frac{(1-\theta)-\theta c_{i}}{\alpha a^{2}(1-\theta)}+\frac{\delta_{i}^{2}}{\gamma_{i}}
$$

The real wage leads to unemployment of

$$
u_{i}=a \cdot \frac{(1-\theta)-\theta c_{i}}{\alpha a^{2}(1-\theta)}
$$

These results give:

Proposition 1: (i) Monetary union has no effect on the amount of deregulation that national unions will accept. The introduction of EMU is irrelevant for labor market regulation from the unions' point of view.

(ii) Nominal wages and inflation in country $i$ will increase if union $i$ is more inflation averse than union $j$.

(iii) Real wages and unemployment will increase in all countries with positive inflation aversion.

Proof: (i) Follows directly from comparing (6) and (12).

(ii) Denote nominal wages before EMU as $w_{i}^{N A T}$ and wages in EMU as $w_{i}^{E M U, N C}$ where NC denotes the case of non-cooperative wage setting. From (5) and (11) the condition for $w_{i}^{E M U, N C}>w_{i}^{N A T}$ is $c_{i}>q(1-2 q)\left(c_{j}-c_{i}\right)$. The comparison of (4) and (10) gives that $\pi_{i}^{E M U, N C}>\pi_{i}^{N A T}$ whenever $c_{i}>1 / 2(1-2 \theta)\left(c_{j}-c_{i}\right)$. Both conditions are fulfilled if $c_{i}>c_{j}$.

(iii) Using (7) and (13) shows that the condition for $\hat{w}_{i}^{E M U, N C}>\hat{w}_{i}^{N A T}$ is $c_{i}>0$. Given equation (1) this implies that employment will fall. Q.E.D.

The intuition for Proposition 1 is that all adjustment unions make is in terms of wage demands. They are not willing, however, to accept changes in the amount of labor market regulation. They have no incentive to change national labor market regulation because monetary union has only an effect via the introduction of a common central bank. EMU changes the trade-off between nominal wage demands, inflation and employment for the labor union. Because it has no effect on 
the relation between rigidities and employment monetary union is irrelevant for labor market regulation, at least from the labor unions' point of view. ${ }^{8}$

With respect to wage setting, labor unions will use the introduction of monetary union to set higher real wages. This is because they realize that the ECB will react less expansionary to a nominal wage increase than the national central bank did before. This improves the unions trade-off between real wages and inflation. Unions are able to achieve higher real wages at a lower rate of inflation. Since all unions perceive this improved trade-off they all react alike implying an increase in unemployment (see Grüner and Hefeker, 1999, for a detailed discussion of this effect). The importance of inflation aversion is obvious because this effect depends on $c_{i}>0$. Otherwise, real wages are not changed by the movement to EMU and therefore the employment effects are zero. In this case, the monetary regime is irrelevant for national unemployment because a labor union could still select its preferred point on the labor demand curve, unaffected by nominal values. ${ }^{9}$

Although real wages increase for all unions, the interaction between nominal wages and central bank reaction to them means that the inflation aversion of union $j$ is important for the nominal wage setting of union $i$. Nominal wages increase if labor union is more inflation averse than union $j$. If labor union $i$ realizes that union $j$ is more inflation averse than itself, this has a disciplinary effect on its own wage setting behavior. The ECB has little reason to inflate because country $j$ is very moderate in its wage demands and the union will consequently moderate its wage demand.

\section{Labor Union Cooperation and Unemployment}

Given the existence of these negative externalities between labor unions, EMU could lead to attempts by national labor unions to coordinate their wage setting and the accepted degree of market deregulation. They have a clear incentive to internalize these negative spillovers by coordinating their behavior. Also, since several initiatives by governments have aimed to coordinate their labor market policies within the European Union (e.g. at the Luxembourg summit in 1997), one

\footnotetext{
${ }^{8}$ As indicated above, this may be different for governments.

${ }^{9}$ Notice that this result holds for all possible degrees of central bank concern for employment and number of national labor unions; see Cukierman and Lippi (1999) and Guzzo and Velasco (1999). Both papers look at several unions in one country but disregard the issue of labor market regulation.
} 
might expect that unions coordinate their response to governments. The impact of such a coordination thus is addressed next.

\section{A. Cooperation of Labor Unions}

Two possible forms of coordination or cooperation can be distinguished. Either unions can try to internalize the negative spillover that is behind the negative employment result derived in section 3 by setting their wages in a cooperative way. This does not necessarily imply that they set them at the same level. The alternative is a full harmonization of wages at a common level. Both alternatives are also possible with regard to the amount of labor deregulation. ${ }^{10} \mathrm{I}$ begin with cooperative setting of wages and labor market regulation.

The joint utility function is given as

$$
U=\frac{1}{2}\left(U_{i}+U_{j}\right)
$$

and maximized with respect to $w_{i}, w_{j}, s_{i}, s_{j}$. Like national central banks in the $\mathrm{ECB}$, unions thus have equal weight, excluding differences in size.

The first order conditions yields nominal wage demands and labor market regulation for country $i$ as

$$
w_{i}=\frac{(1-2 \theta)-\theta\left(c_{i}+c_{j}\right)}{\alpha a^{2}(1-2 \theta)^{2}}+\delta_{i} s_{i}
$$

and

$$
s_{i}=\frac{\delta_{i}}{\gamma_{i}}
$$

Using (17) in (16) and (10) and (1), the real wage and unemployment are

$$
\hat{w}_{i}=\frac{(1-2 \theta)-\theta\left(c_{i}+c_{j}\right)}{\alpha a^{2}(1-2 \theta)^{2}}+\frac{\delta_{i}^{2}}{\gamma_{i}}
$$

and

$$
u_{i}=a \cdot \frac{(1-2 \theta)-\theta\left(c_{i}+c_{j}\right)}{\alpha a^{2}(1-2 \theta)}
$$

\footnotetext{
${ }^{10}$ Sibert and Sutherland (2000) consider only joint wage setting of symmetric unions, arguing that labor market regulation is not contractable. Since labor market reform is well observable I find this argument not compelling.
} 
This leads to Proposition 2.

Proposition 2: In case that labor unions in EMU members countries set wages and labor market regulation cooperatively:

(i) Labor market regulation is still unaffected by EMU.

(ii) Nominal wages and inflation in country $i$ increase if union $i$ is more inflation averse than union $j$. In this case, real wages and unemployment increase too.

(iii) Cooperation can be counterproductive if $c_{i}$ is much larger than $c_{j}$. Then real wages and unemployment are even higher than in the non-cooperative case.

Proof: (i) The first part of the proposition follows directly from comparing (6) and (17).

(ii) The common condition for $w_{i}^{E M U, C}>w_{i}^{N A T}, \pi^{E M U, C}>\pi_{i}^{N A T}, \hat{w}_{i}^{E M U, C}>\ddot{\pi}_{i}^{N A T}$, is $c_{i}>c_{j}$. If real wages increase, equation (i) implies that unemployment in country $i$ increases as well.

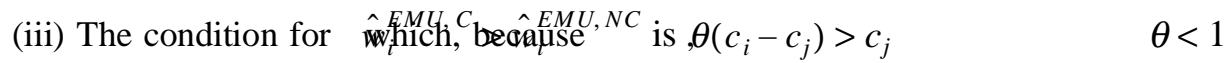
is only fulfilled if $c_{i}$ is much larger than $c_{j}$, or if $c_{j}=0$. In this case unemployment would also be higher than in the non-cooperative case. Q.E.D.

The benefits of cooperation are unequally distributed. For labor unions whose inflation aversion is low, cooperation in EMU means that real wages and unemployment fall with cooperation upon entering the monetary union. This is different for labor unions which are more inflation averse than the other unions. Even with cooperation the same logic that applies to the non-cooperative case is valid. The unions still use the mediated central bank response to nominal wages to increase their wage demands. Inflation will increase but not enough to lower real wages. Hence, unemployment increases. Cooperation can even be counter productive in terms of unemployment compared to non-cooperative behavior for those unions which cooperate with a union that is not inflation averse $\left(c_{j}=0\right)$, or that are much more inflation averse than their counterpart. Nevertheless, even with cooperation unions will continue to separate the issues of wage setting and regulation. This confirms the result that monetary union and deregulation of labor markets are separate issues.

\section{B. Full Harmonization}

Another way of cooperative wage setting would be joint and harmonized setting of wages and labor market regulation. One could imagine that cooperation might actually imply joint setting of wages and regulations (see OECD, 1999, for such 
an argument). In fact, many national labor unions make the case for an EMU wide harmonized regime of labor standards. Although it is doubtful that such a regime would really be implemented, it might be useful to check whether this would, as some unions claim, really be necessary to avoid unemployment or be even unemployment increasing.

Again, unions maximize $U=1 / 2\left(U_{i}+U_{j}\right)$ but this time by setting a common wage and a common level of labor standards and regulation. Maximizing the joint utility function gives for both countries with respect to a common $w$ and $s$ yields

$$
W_{i}=\frac{(1-2 \theta)-\theta\left(c_{i}+c_{j}\right)}{\alpha a^{2}(1-2 \theta)^{2}}+\frac{\left(\delta_{i}+\delta_{j}\right)}{2} s
$$

and

$$
s=\frac{\left(\delta_{i}+\delta_{j}\right)}{\left(\gamma_{i}+\gamma_{j}\right)+\alpha a^{2} \frac{1}{2}\left(\delta_{i}-\delta_{j}\right)^{2}}
$$

As equation (20) unsurprisingly shows, the joint nominal wage demand set by the two unions is decreasing in the sum of the inflation aversions of the two unions and increasing in the sum of the degree of labor market deregulations. It is similar to the cooperative wage set and differs only in the deregulation term (cf. (16)). The higher deregulation in one country, the more the other union profits from higher nominal wages.

The most obvious change is in the degree of labor market deregulation (21). It is no longer determined by the national impact of regulation on unemployment but by the sum of the two national parameters. The same is true for the influence of the aversion to deregulation. Clearly, the more the two parameter differ between country $i$ and country $j$, the larger the change for every single country is from moving to harmonized labor market regulation.

The nominal wage derived implies the following real wage

$$
\hat{w}=\frac{(1-2 \theta)-\theta\left(c_{i}+c_{j}\right)}{\alpha a^{2}(1-2 \theta)^{2}}+\frac{1}{2} \cdot \frac{\left(\delta_{i}+\delta_{j}\right)^{2}}{2\left(\gamma_{i}+\gamma_{j}\right)+\alpha a^{2}\left(\delta_{i}-\delta_{j}\right)^{2}}
$$

for both countries. By using (22) in (1), unemployment in country $i$ becomes

$$
u_{i}=a \cdot\left[\frac{(1-2 \theta)-\theta\left(c_{i}+c_{j}\right)}{\alpha a^{2}(1-2 \theta)^{2}}+\frac{1}{2} \frac{\delta_{i}^{2}+\delta_{j}^{2}}{\left(\gamma_{i}+\gamma_{j}\right)+\alpha a^{2} \frac{1}{2}\left(\delta_{i}-\delta_{j}\right)^{2}}\right]
$$


These results lead to:

Proposition 3: In case that labor unions harmonize wage demands and the degree of labor market deregulation: (i) Labor market deregulation in country $i$ will change whenever $\delta_{i} \neq \delta_{j}$ or $\gamma_{i} \neq \gamma_{j}$.

(ii) If deregulation in country $i$ increases and union $i$ is more inflation averse than union $j$ nominal wages and real wages in country $i$ increase. If union $i$ is more inflation averse, inflation will rise as well.

(iii) Unemployment in country $i$ will increase if aind $c_{j} \quad \delta_{j}>\delta_{i}$

Proof: (i) Is obvious from (6) and (21).

(ii) Let the change in the amount of labor regulation in country $i$ be defined as $\Delta s_{i}=s-s_{i}$ where $s$ is given by (21) and $s_{i}$ by (6). Then $\Delta s_{i}=\left[\gamma_{i}\left(\delta_{i}+\delta_{j}\right)^{2}-\right.$ $\left.\delta_{i}^{2} 2\left(\gamma_{i}+\gamma_{j}\right)+\alpha a^{2}\left(\delta_{i}-\delta_{j}\right)^{2}\right] /\left(\gamma_{i}\left[2\left(\gamma_{i}+\gamma_{j}\right)+\alpha a^{2}\left(\delta_{i}-\delta_{j}\right)^{2}\right]\right)$. This expression is likely to be positive if $\gamma_{i}$ is relatively large in comparison to $\gamma_{j}$ and if $\delta_{j}$ is relatively large compared to $\delta_{i}$. In this case, the influence of country $j$ on the common degree of regulation increases deregulation in country $i$.

The condition for $w^{E M U, H}>w_{i}^{N A T}$ is $\left.\Delta s_{i}>\theta\left(c_{j}-c_{i}\right) / \alpha a^{2}(1-2 \theta)^{2}\right]$, that for $\hat{w}^{E M U, H}>\hat{w}_{i}^{N A T}$ is $\Delta s_{i}>\theta\left(c_{j}-c_{i}\right) / \alpha a^{2}(1-2 \theta)^{2}$, and $\pi^{E M U, H}>\pi_{i}^{N A T}$ requires $1 / 2\left(\delta_{j}+\delta_{i}\right) s>\theta\left(c_{j}-c_{i}\right) / \alpha a^{2}(1-2 \theta)^{2}$. The first two conditions are fulfilled if $c_{i}>c_{j}$ and if $\Delta s_{i}>0$. The third condition is fulfilled if $c_{i}>c_{j}$.

(iii) The condition for $u_{i}^{E M U, H}>u_{i}^{N A T}$ is $1 / 2\left(\delta_{j}-\delta_{i}\right) s>\theta\left(c_{j}-c_{i}\right) / \alpha a^{2}(1-2 \theta)$ which is fulfilled for $c_{i}>c_{j}$ and $\delta_{j}>\delta_{i}$ Q.E.D.

This proposition shows that full harmonization is counterproductive for employment in certain cases. The joint determination of deregulation can imply for one country that it liberalizes its labor market. This will be the case if the other labor union is not very deregulation averse (a small $\gamma_{j}$ ) and/or deregulation has a strong beneficial effect for employment (a large $\delta_{j}$ ). Given joint determination of labor market regulation, this implies for countries that are deregulation averse an increase in flexibility. The second effect that matters is the difference in inflation aversion. If union $i$ is more inflation averse, the influence of $j$ implies higher wages for $i$. If in addition union $j$ is not very concerned with inflation this additionally pushes up the joint wage. As a result nominal and real wages increase compared with the situation before EMU.

This result suggests that, contrary to what is often argued by economists and international organizations, deregulation need not imply that real wages will fall in the process of regulation. Deregulation that does not affect the power of unions might even lead them to demand higher wages. As deregulation increases employ- 
ment, labor unions use the improved employment situation to set higher wages. If thus harmonized regulation implies that labor market rigidities in country $i$ are reduced because union $j$ favors a liberal labor market, labor union $i$ would require a compensation in terms of higher wages. The common wage is additionally pushed up if union $j$ is not very inflation averse and thus not "disciplined enough" in its wage setting preferences. For this reason harmonized wages and labor market regulation could in fact further increase unemployment in those countries that are very inflation averse and, at the same time, very averse to deregulation of the labor market.

As already indicated above, this result is driven by the assumption that higher deregulation would not affect the wage setting process as such. I have maintained the assumption that labor unions are monopolistic, even in a very deregulated labor market. This assumption might be unrealistic, although in this model there is no room for deregulation to influence the wage setting process. Here, powerful unions can set labor market regulation themselves and the outcome is thus driven by their preferences alone. The results in this section should thus be taken cautiously. Nevertheless, it seems intuitive that harmonization can produce ambiguous results, whereas non-cooperative behavior and cooperative behavior have clear implications.

\section{Conclusion}

This paper has analyzed the question whether labor market regulation in a monetary union is likely to increase or decrease if labor unions can determine those. In contrast to the recent literature that has shown that labor market reform will be reversed when governments can determine the reform level alone, the paper has shown that this result is not general. In countries where labor unions have an important role in determining labor market reform, it is unlikely that EMU has a strong effect on the amount of labor regulation. It seems at least incomplete to assume that governments could easily change labor market legislation without taking the interest of labor into account. Therefore, analyses focusing on governments' incentives only can be misleading as a prediction for labor market regulation under EMU. For the unions, however, monetary union and real aspects of the labor market are two completely separated issues. Thus, the main result of this paper is that the introduction of EMU need not change the preferences of unions with regard to labor market regulation. This incidentally implies that my results 
are a bit more optimistic concerning deregulation than those of earlier analyses.

This is not true for the level of wages though. It follows unambiguously that real wages are likely to go up in the EMU, simply because the introduction of a new central bank alters unions' trade offs between inflation, employment and real wages. However, this result depends crucially on the introduction of inflation aversion on the side of labor unions as well. The introduction of the euro creates a spillover effect in which unions use the improved trade off between wage demands and employment to demand higher wages. Thus, with non-cooperative wage setting, EMU increases real wages in each member country and therefore lowers employment. This result is modified if unions cooperate in their wage setting behavior or even to harmonize it. In this case, the difference in the preferences of the labor unions become important. In general, it can be said that those countries whose labor unions are very inflation averse will experience an increase in wage demands, in the rate of inflation and in unemployment. Therefore, an European wide labor market regulation is not employment improving for all countries.

\section{Acknowledgements}

For helpful comments I thank Udo Broll, Laszlo Goerke, Steinar Holden, Georg Nöldeke and Adam Posen, and two anonymous referees. I am also grateful to seminar participants in Basel, Saarbrücken and Vienna, and to conference participants in Boston (AEA), Rostock (VfS) and Santiago de Compostela (EEA).

Date accepted: April, 2000

\section{References}

Belke, A. and M. Kamp (1999), "Do Labour Market Reforms Achieve a Double Dividend under EMU? Discretionary versus Rule-based Monetary Policy Revisited," Journal of Economic Integration 14, 572-605.

Calmfors, L. (2000), "Unemployment, Labour-Market Reform and Monetary Union," Journal of Labor Economics, forthcoming.

Coe, D. T. and D. J. Snower (1997), "Policy Complementarities: The Case for Fundamental Labor Market Reform," IMF Staff Papers 44, 1-35.

Cubitt, R.P. (1992), "Monetary Policy Games and Private Sector Precommitment," Oxford Economic Papers 44, 513-530. 
Cukierman, A. and F. Lippi (1999), "Central Bank Independence, Centralization of Wage Bargaining, Inflation and Unemployment-Theory and Evidence," European Economic Review 43, 1395-1434.

Cukierman, A. and F. Lippi (2000), "Labor Markets and Monetary Union: A Strategic Analysis," Economic Journal, forthcoming.

Grüner, H. P. (1999), On the Role of Conflicting National Interests in the ECB Council, CEPR Discussion Paper 2192.

Grüner, H. P. and C. Hefeker (1998), "How Will EMU Affect Unemployment and Inflation?," Scandinavian Journal of Economics 101, 33-47.

Guzzo, V. and A. Velasco (1999), "The Case for a Populist Central Banker," European Economic Review 43, 1317-1344.

Hefeker, C. (1999), Labour Market Structure and Monetary Union in Europe. Does it Make a Difference?, Centre for European Policies Studies, Brussels.

Horn, H. and T. Persson (1988), "Exchange Rate Policy, Wage Formation and Credibility," European Economic Review 32, 1621-1636.

Jackman, R. (1997), "EU Labor Markets Inside and Outside the Monetary Union, in P. Welfens," ed: European Monetary Union, Berlin: Springer, 297-323.

Lawler, P. (2000), "Centralised Wage Setting, Inflation Contracts, and the Optimal Choice of Central Banker," Economic Journal 110, 559-575.

OECD (Organization for Economic Co-operation and Development) (1994), The OECD Job Study: Evidence and Explanations, Paris: OECD.

OECD (Organization for Economic Co-operation and Development) (1999), EMU: Facts, Challenges and Policies, Paris: OECD.

Oswald, A. (1985), "The Economic Theory of Trade Unions: An Introductory Survey," Scandinavian Journal of Economics 87, 160-193.

Rama, M. (1994), "Bargaining Structure and Economic Performance in the Open Economy," European Economic Review 38, 403-415.

Saint-Paul, G. (1996), "Exploring the Political Economy of Labour Market Institutions," Economic Policy 23, 263-315.

Sibert, A. and A. Sutherland (2000), "Monetary Regimes and Labour Market Reform," Journal of International Economics 51, 421-435.

Siebert, H. (1997), "Labor Market Rigidities: At the Root of Unemployment in Europe," Journal of Economic Perspectives 11 (Summer), 37-54. 